\title{
FAKTOR YANG MEMPENGARUHI IBU YANG MEMILIKI BALITA DALAM IMPLEMENTASI PROGRAM KELUARGA SADAR GIZI (KADARZI) DI WILAYAH KERJA PUSKESMAS PAYUNG SEKAKI PEKANBARU
}

\author{
Husna Farianti Amran \\ Program Studi D-III Kebidanan STIKes Payung Negeri Pekanbaru \\ Korespondensi penulis: na.farianti@gmail.com
}

\begin{abstract}
Abstrak
Latar belakang dan Tujuan: Menurut WHO, faktor gizi merupakan 54\% kontributor penyebab kematian. Balita kurang gizi di dunia meningkat 75 juta menjadi 923 juta. Di Indonesia, persentase anak balita (balita) mengalami gizi buruk 5,4\% dan gizi buruk 17,9\%. Di Provinsi Riau, prevalensi $1,1 \%$ kekurangan gizi sedikit meningkat sebesar 1,03\%. Prevalensi gizi buruk adalah 7,9\%, meningkat $7,7 \%$. Penelitian bertujuan menganalisis faktor-faktor yang mempengaruhi implementasi Program Keluarga Sadar Gizi (Kadarzi) pada ibu yang memiliki Balita di Wilayah Kerja Puskesmas Payung Sekaki Pekanbaru yang meliputi Pengetahuan, sikap, social budaya dan pendidikan.

Metode: Jenis penelitian kuantitaif dengan desain analitik dengan pendekatan coss sectional. Populasi seluruh Ibu yang memiliki Balita di Wilayah Kerja Puskesmas Payung Sekaki yang berjumlah 10.774 orang, dengan sampel 100 orang diambil dengan teknik pusposive Sampling. Penelitian dilakukan bulan November-Desember 2019. Data dikumpulkan menggunakan kuesioner dan dianalisa secara univariate dan bivariate.

Hasil: Hasil penelitian diperoleh faktor-faktor yang secara statistik memiliki kemaknaan signifikan mempengaruhi implementasi Program Keluarga Sadar Gizi (Kadarzi) pada ibu yang memiliki Balita adalah Pengetahuan $(P$ value 0,025$)$, Sikap $(P$ value 0,003$)$, Sosial Budaya $(P$ value 0,029$)$, dan Pendidikan (P value 0,018)

Simpulan: Faktor-faktor yang mempengaruhi implementasi program Keluarga Sadar Gizi (Kadarzi) pada ibu yang memiliki Balita meliputi: Pengetahuan, sikap, sosial budaya dan Pendidikan.
\end{abstract}

Kata Kunci: Keluarga Sadar Gizi, Pengetahuan, Sikap, Sosial Budaya dan Pendidikan

\section{Pendahuluan}

Masalah gizi terjadi disetiap siklus kehidupan, dimulai sejak dalam kandungan (janin), bayi, anak, dewasa dan usia lanjut. Keadaan gizi yang baik merupakan syarat terciptanya sumber daya manusia masa depan yang berkualitas (Kemenkes, 2014).Kelaparan dan gizi buruk menjadi masalah gizi terberat dan ancaman bagi 1 miliar penduduk dunia termasuk Indonesia. Menurut Global Hunger Index (GHI) Indonesia masuk dalam katagori serius dengan skor 20.1 yang berada pada level sangat mengkhawatirkan. Indonesia merupakan peringkat 70 dari 117 negara yang memenuhi syarat. Skor GHI tersebut menghubungkan komponen yaitu kekurangan gizi, kekerdila anak dan kematian anak. (GHI, 2019)

Berdasarkan Pemantauan Status Gizi (PSG) 2017 yang dilakukan Kementrian Kesehatan, Balita yang mengalami masalah gizi pada tahun 2017 mencapai 17,8\%, sama dengan tahun sebelumnya. Jumlah tersebut terdiri dari Balita yang mengalami gizi buruk $3,8 \%$ dan $14,0 \%$ gizi kurang. (Kemenkes, 2018) 
Anak dibawah lima tahun (Balita) merupakan kelompok yang menunjukkan pertumbuhan badan yang pesat namun kelompok ini merupakan kelompok tersering yang menderita kekurangan gizi. Gizi ibu yang kurang atau buruk pada waktu konsepsi atau sedang hamil muda dapat berpengaruh kepada pertumbuhan semasa balita. Bila gizi buruk maka perkembangan otaknya pun kurang dan itu akan berpengaruh pada kehidupannya diusia sekolah dan prasekolah (Proverawati dan Asfuah, 2009).

Berdasarkan hasil Pemantauan Status Gizi Balita Provinsi Riau Tahun 2015 diperoleh prevalensi status gizi buruk $1,03 \%$, dan mengalami peningkatan sedikit pada tahun 2016, yaitu $1,1 \%$. Prevalensi status gizi kurang tahun 2015 adalah $7.7 \%$, terjadi peningkatan 7,9\% hasil PSG tahun 2016, kemudian balita bergizi baik 88,2\%, sedangkan balita dengan status gizi lebih 2,1\% (Dinkes Provinsi Riau, 2016).

Untuk mengatasi permasalahan gizi pada balita, harus dimulai dari peran keluarga sebagai unit terdekat dalam tumbuh kembang Balita. Keluarga Sadar Gizi (KADARZI) adalah salah satu keluarga yang mampu mengenal, mencegah dan mengatasi masalah gizi setiap anggotanya. Suatu keluarga disebut Kadarzi apabila telah berperilaku gizi yang baik yang dicirikan minimal dengan: menimbang berat badan secara teratur, memberikan ASI saja kepada bayi sejak lahir sampai umur enam bulan (ASI Eksklusif), makan beraneka ragam, menggunkan garam beryodium, minum suplemen gizi sesuai anjuran (Depkes, 2007).

Berdasarkan Profil Kesehatan RI 2017 yang telah dilakukan pada tahun 2016 diperoleh hasil beberapa indikator Kadarzi masih di bawah target yaitu menimbang berat badan sebesar $77,95 \%$, persentase bayi baru lahir yang mendapatkan IMD sebesar 73,06\% target $44 \%$, cakupan pemeberian vitamin A pada balita adalah sebesar 94,73\% lebih tinggi dari target nasional sebesar $82 \%$, keluarga menggunakan garam beryodium pemberian tablet tambah darah pada ibu hamil sebesar $91,8 \%$, dari target pencapaian $90 \%$, pemberian vitamin A pada ibu nifas sebanyak
93,8\% target 80\%. Riskesdes 2013 mendapatkan anemia terjadi pada $37,1 \%$ ibu hamil di Indonesia, 36,4\% ibu hamil di perkotaan dan $37,8 \%$ ibu hamil di pendesaan. Cakupan pemberian TTD pada ibu hamil di Indonesia tahun 2017 adalah 80,81\%. Angka ini belum mencapai target yaitu $90 \%$.

Berdasarkan Dinas Kesehatan Provinsi Riau 2016, Jumlah anak balita yang dibawa ke posyandu untuk ditimbang sebagai upaya deteksi dini gangguan pertumbuhan sekitar $63,7 \%$ (target $80 \%$ ). Bayi dan balita yang telah mendapat kapsul vitamin A baru mencapai $83,6 \%$ (target $85 \%$ ) dan ibu hamil yang mengkonsumsi Tablet Tambah Darah (TTD) baru mencapai 66,49\% (target 90\%). Demikian pula dengan perilaku gizi lainnya juga masih belum baik yaitu masih rendahnya ibu yang menyusui bayi 0-6 bulan secara eksklusif yang baru mencapai 56,2\% (target $80 \%$ ) sekitar $28 \%$ (target $80 \%$ ) rumah tangga belum menggunakan garam beryodium yang memenuhi syarat, dan pola makan yang belum beraneka ragam.

Pengetahuan dan sikap yang dimiliki seseorang merupakan faktor predisposisi yang memengaruhi perilaku. Jika ibu memiliki pengetahuan yang baik tentang gizi balita, diharapkan ibu juga akan memiliki sikap dan perilaku yang baik pula dalam pemenuhan gizi balita. Pengetahuan ibu mengenai gizi akan berpengaruh terhadap hidangan dan mutu makanan yang disajikan untuk anggota keluarga termasuk balita. Sikap ibu dalam memenuhi kebutuhan gizi balita juga sangat penting. Sikap merupakan faktor yang memengaruhi perilaku kesehatan seseorang. Perubahan sikap secara berkelanjutan dapat memengaruhi perilaku seseorang, dimana perilaku pemenuhan gizi yang baik dapat meningkatkan status gizi anak (Setyaningsih dan Agustini, 2014).

Faktor lain yang juga mempengaruhi perilaku ibu dalam menerapkan program Kadarzi adalah Sosial Budaya. Larangan terhadap anak untuk makan telur, ikan atau daging hanya berdasarkan kebiasaan yang tidak ada datanya dan hanya diwarisi secara dogmatis secara turun temurun, padahal anak itu sendiri sangat memerlukan bahan makanan 
seperti itu guna keperluan pertumbuhan tubuhan anak. (Proverawati, 2010)

Berdasarkan data Dinas Kesehatan Kota Pekanbaru tahun 2018, Puskesmas Payung Sekaki merupakan salah satu dari 3 kunjungan balita terbanyak di Kota Pekanbaru yaitu (10.891). Untuk itu penulis merasa tertarik untuk mengangkat masalah ini untuk dijadikan bahan penelitian. Adapun dalam penelitian ini penulis mengangkat judul "Faktor yang mempengaruhi Ibu yang memiliki Balita dalam Implementasi Program Keluarga Sadar Gizi (KADARZI) Di Wilayah Kerja Puskesmas Payung Sekaki Pekanbaru tahun 2019"

\section{Metode Penelitian}

Jenis penelitian adalah kuantitatif desain analitik dengan pendekatan cross sectional. Penelitian dilakukan pada bulan November Desember 2019. Populasi dalam penelitian ini adalah seluruh ibu-ibu yang mempunyai anak Balita di Wilayah Kerja Puskesmas Payung Sekaki Pekanbaru tahun 2018 sebanyak 10.774 orang. Dan diambil sampel sebanyak 100 orang.dengan menggunakan teknik purposive sampling. Instrument pengumpulan data yang digunakan adalah kuesioner berupa daftar pertanyaan untuk mengetahui variabel yang diteliti. Analisa Data yang digunakan adalah analisa Univariate dan bivariate dengan menggunakan uji chi-squre $\left(\mathrm{X}^{2}\right)$.

3. Hasil dan Pembahasan

Tabel 1. Distribusi Frekuensi Karakteristik Responden di Wilayah Kerja Puskesmas Payung Sekaki Pekanbaru tahun 2019

\begin{tabular}{llcc}
\hline No & \multicolumn{1}{c}{ Kategori } & Frekuensi & \% \\
\hline $\mathbf{1}$ & Pengetahuan & & \\
& - Tinggi & 67 & 67 \\
& - Rendah & 33 & 33 \\
\hline $\mathbf{2}$ & Sikap & & 64 \\
& $-\quad$ Positif & 64 & 36 \\
& - Negatif & 36 & 62 \\
\hline $\mathbf{3}$ & Sosial Budaya & & 38 \\
& - Mendukung & 62 & 37 \\
& - Tidak mendukung & 38 & 63 \\
\hline $\mathbf{4}$ & Pendidikan & 37 & \\
& - Tinggi & 63 & 62 \\
& - Menengah & & 38 \\
\hline $\mathbf{5}$ & Implementasi Kadarzi & & \\
& - Positif & 61 & \\
& - Negatif & 39 & \\
\hline
\end{tabular}

Tabel 2. Hubungan Karakteristik Responden Dengan Implementasi Program Keluarga Sadar Gizi (Kadarzi) di Wilayah Kerja Puskesmas Payung Sekaki Pekanbaru tahun 2019

\begin{tabular}{|c|c|c|c|c|c|c|}
\hline \multirow{3}{*}{ Karakteristik } & \multicolumn{4}{|c|}{ Perilaku Penggunaan Buku KIA } & \multirow{3}{*}{$\mathbf{N}$} & \multirow{3}{*}{$P$ value } \\
\hline & \multicolumn{2}{|c|}{ postif } & \multicolumn{2}{|c|}{ Negatif } & & \\
\hline & $\mathbf{n}$ & $\%$ & $\mathbf{N}$ & $\%$ & & \\
\hline \multicolumn{7}{|l|}{ Pengetahuan } \\
\hline Tinggi & 46 & 68,7 & 21 & 31,3 & 67 & 0,025 \\
\hline Rendah & 15 & 45,4 & 18 & 54,6 & 33 & \\
\hline \multicolumn{7}{|l|}{ Sikap } \\
\hline Positif & 46 & 71,8 & 18 & 28,2 & 64 & 0,003 \\
\hline Negatif & 15 & 23,8 & 21 & 76,2 & 36 & \\
\hline \multicolumn{7}{|l|}{ Sosial Budaya } \\
\hline Mendukung & 43 & 69,4 & 19 & 30,6 & 62 & 0,029 \\
\hline Tidak mendukung & 18 & 47,4 & 20 & 52,6 & 38 & \\
\hline
\end{tabular}




\begin{tabular}{lllllll}
\hline $\begin{array}{l}\text { Pendidikan } \\
\text { Tinggi }\end{array}$ & 20 & 54,1 & 17 & 45,9 & 37 & 0,018 \\
Menengah & 44 & 69,8 & 19 & 30,2 & 63 & \\
\hline
\end{tabular}

Berdasarkan tabel 1 diketahui bahwa responden di Wilayah kerja Puskesmas Payug Sekaki Pekanbaru berada pada kategori pengetahuan tinggi yaitu 67 responden $(67 \%)$, memiliki sikap positif yaitu 64 orang $(64 \%)$, memiliki social budaya yang mendukung yaitu 62 orang (62\%), kategori pendidikan menengah yaitu 63 orang $(63 \%)$ dan mengimplementasikan Kadarzi postif yaitu 61 orang $(61 \%)$.

Dari hasil analisa bivariate untuk mengetahui hubungan variabel dependen dan independen. Berdasarkan analisa bivariate dengan menggunakan uji chi-quare diperoleh hasil bahwa variabel-variabel memiliki kemaknaan secara statistik yaitu Pengetahuan ( $P$ value 0,025$)$, Sikap ( $P$ value 0,003$)$, Sosial Budaya $(P$ value 0,029$)$, dan Pendidikan $(P$ value 0,018$)$.

\section{Pembahasan}

Faktor yang berhubungan dengan Implementasi Program Keluarga Sadar Gizi (Kadarzi) dapat dilihat dari pengetahuan, Sikap, Sosial Budaya dan Pendidikan Responden. Pada penelitian ini semua factorfaktor tersebut memiliki kemaknaan secara statistik terhadap Implementasi Program Keluarga Sadar Gizi (Kadarzi) oleh ibu yang memiliki Balita.

a. Hubungan Pengetahuan Ibu yang memiliki Balita dengan Implementasi Program Keluarga Sadar Gizi (Kadarzi)

Dari hasil penelitian diketahui bahwa Mayoritas Pengetahuan Responden berada pada kategori Pengetahuan Tinggi yaitu 67 responden (67\%). Hasil uji statistik menunjukkan terdapat hubungan yang signifikan antara pengetahuan dengan implementasi program Kadarzi Pada ibu yang memiliki Balita $P$ value 0,025 ( $P<0,025)$.

Pemerintah telah mencanangkan program Keluarga Sadar Gizi (Kadarzi) dengan harapan masalah gizi akan berkurang. Keluarga Sadar Gizi (Kadarzi) adalah keluarga yang seluruh anggota keluarga melakukan perilaku gizi seimbang, mampu mengenali masalah kesehatan dan gizi bagi anggota keluarganya dan mampu mengambil langkah-langkah untuk mengatasi masalah gizi yang dijumpai anggota keluarganya. Indicator kadarzi pada ibu yang memiliki Balita adalah $80 \%$ balita ditimbang setiap bulan, $80 \%$ bayi $0-6$ bulan diberi ASI saja (ASI Eksklusif), 90\% keluarga menggunakan garam beryodium, $80 \%$ keluarga makan beraneka ragam sesuai kebutuhan, memberikan Suplemen Gizi Sesuai Aturan. dan $80 \%$ balita dan ibu nifas mendapatkan kapsul vitamin A sesuai anjuran. (Depkes, 2007).

Hasil penelitian menunjukkan Responden berada pada kategori Pengetahuan Tinggi yaitu 67 responden (67\%). Pengetahuan adalah hasil tahu dan terjadi setelah seseorang melakukan penginderaan suatu objek tertentu. Penginderaan terjadi melalui panca indera manusia, yaitu penglihatan, pendengaran, penciuman, perasa dan raba. Sebagian besar manusia diperoleh melalui mata dan telinga (Notoatmodjo, 2012).

Pengetahuan dapat mempengaruhi perilaku ibu dalam mengimplementasikan program keluarga sadar gizi (Kadarzi). Apabila penerimaan perilaku didasari oleh pengetahuan maka perilaku tersebut akan berlangsung lama. Salah satu faktor yang mempengaruhi status gizi pada anak adalah pengetahuan ibu dalam memilih dan memberikan makanan, karena pengetahuan ibu mempengaruhi bagaimana perilaku ibu memenuhi persediaan pangan individu keluarganya, mengkonsumsi makanan sesuai kaidah gizi yang benar, memilih jenis makanan serta memprioritaskan makanan ditengah keluarganya. Perilaku ibu yang masih rendah dapat disebabkan karena kurangnya tingkat pengetahuan ibu tentang gizi dan kurangnya kemampuan dalam menerapkan dalam kehidupan sehari-hari (Susanti dkk, 2014).

Penelitian ini juga didukung oleh penelitian Arbella VM, dkk (2013) yang 
menyatakan terdapat hubungan antara pengetahuan tentang keluarga sadar gizi (Kadarzi) dengan Perilaku Sadar Gizi p value $0,001 \quad(\mathrm{p}<0,005)$ dimana responden yang memiliki pengetahuan baik tentang Kadarzi memiliki perilaku baik tentang Kadarzi.

Menurut asumsi peneliti peneliti mayoritas responden yang memiliki pengetahuan tinggi tentang Kadarzi memahami dengan baik indicator kadarzi dan dapat mengimplementasikan program Kadarzi dalam keluarga.

b. Hubungan Sikap Ibu yang memiliki Balita dengan Implementasi Program Keluarga Sadar Gizi (Kadarzi)

Berdasarkan hasil penelitian diketahui bahwa mayoritas responden sudah memiliki sikap yang positif tentang Kadarzi yaitu 64 responden (64\%). Responden yang memiliki sikap positif tentang Kadarzi mereka memiliki suatu pemikiran yang benar dan tepat tentang gizi Balitanya. Mereka tahu bahwa nutrisi penting untuk bayi dan balitanya. Dari penelitian ternyata masih terdapat ibu balita yang memiliki sikap negatif tentang keluarga sadar gizi yaitu sebanyak 36 responden (36\%).

Berdasarkan hasil analisa bivariate diketahui bahwa terdapat hubungan yan signifikan antara sikap $P$ value 0,003 $(\mathrm{p}<0,005)$ dengan implementasi Kadarzi. Hal ini menunjukkan responden yang memiliki sikap postif mengimplementasikan Kadarzi dengan positif yaitu 46 responden $(71,8 \%)$

Sikap dapat diposisikan sebagai hasil evaluasi terhadap obyek sikap yang diekspresikan ke dalam proses-proses kognitif, afektif (emosi) dan perilaku. Dari definisi-definisi diatas menunjukkan bahwa secara garis besar sikap terdiri dari komponen kognitif (pengetahuan suatu objek), perilaku (kecendrungan untuk bertindak) dan emosi yang menyebabkan respon-respon yang konsisten senang, benci dan sedih (Maulana, 2012).

Sikap responden pada katagori positif dapat ditunjang oleh pengetahuan responden pada katagori tinggi. Menurut Azwar (2008) beberapa faktor yang dapat mempengaruhi sikap seseorang diantaranya pengalaman pribadi yaitu untuk menyadari dasar pembentukan sikap, pengalaman pribadi harus melalui kesan yang kuat. Oleh karena itu sikap akan mudah terbentuk jika faktor emosional terlibat dalam pengalaman pribadi. Pengalaman pribadi ini sifatnya saling terkait dalam kehidupan seseorang.

Sikap merupakan faktor pendorong perilaku (Reinforcing Factors) yaitu faktor yang memperkuat perubahan perilaku seseorang. Tahapan perubahan perilaku yang pertama adalah adanya pengetahuan yang kemudian dipersepsikan dalam sikap. Ibu yang mengetahui dan memahami tentang indikator Kadarzi aan bersikap sesuai dengan yang diketahuinya dan proses selanjutnya diharapkan terjadinya perilaku Kadarzi. Notoadmodjo (2010) berpendapat bahwa sikap merupakan kesiapan atau kesediaan untuk bertindak taua berperilaku. Oleh karena itu, sikap ibu yang positif tentang Kadarzi akan memberikan kesiapan atau kesediaan yang baik untuk melaksanakan Kadarzi.

Faktor yang dapat mendukung terbentuknya sikap adalah media masa. Media masa seperti dalam pemberitaan surat kabar maupun radio atau media komunikasi lainnya, berita yang seharusnya faktual disampaikan secara obyektif berpengaruh terhadap sikap konsumennya. Informasi yang disampaikan melalui berbagai sarana informasi yang berbentuk media masa seperti televisi, radio, surat kabar, majalah, dan lain-lain memberikan landasan kognitif bagi terbentuknya sikap. Apabila pesan-pesan yang disampaikan itu cukup sugestif, akan memberi dasar afektif dalam terbentuknya sikap.

Hasil penelitian ini juga didukung oleh Septian.D dan Helmy.R (2013) tentang Pengetahuan dan Sikap Keluarga dengan Perilaku Keluarga Sadar Gizi (Kadarzi) di Provinsi Lampung diketahui bahwa mayoritas sikap responden tentang Kadarzi berada pada kategori sikap positif yaitu $65,1 \%$.

Penelitian berasumsi walaupun ibu memiliki keterbatasan pengetahuan dalam 
mengetahui istilah keluarga sadar gizi pada balitanya, namun ibu memiliki kemauan dan keinginan untuk mencegah masalah gizi pada anak, sehingga sikapnya pun baik. Hal ini dibuktikan dengan hasil analisis menyatakan semua ibu akan terus memberikan makanan seimbang kepada anak walaupun anaknya sulit makan. Hasil analisa pada penelitian ini menunjukkan bahwa status gizi anak yang baik dilatarbelakangi oleh sikap ibu dalam pemenuhan gizi anak. Pengaruh yang signifikan antara sikap ibu dengan status gizi balita. Ibu yang memiliki sikap positif lebih besar dari pada ibu yang memiliki sikap negatif.

\section{c. Hubungan Sosial Budaya dengan Implementasi Program Keluarga Sadar Gizi (Kadarzi)}

Berdasarkan hasil penelitian diketahui bahwa mayoritas responden memiliki sosial budaya yang mendukung tentang Kadarzi yaitu 62 responden (62\%). Responden yang memiliki sosial budaya yang mendukung tentang Kadarzi berada pada lingkungan yang mendukung tumbuh kembang Balita dengan gizi yang optimal. Dari penelitian ternyata masih terdapat ibu balita yang memiliki sikap negatif tentang keluarga sadar gizi yaitu sebanyak 38 responden $(38 \%)$.

Berdasarkan hasil analisa bivariate diketahui bahwa terdapat hubungan yan signifikan antara dukungan social budaya $P$ value $0,029(\mathrm{p}<0,005)$ dengan implementasi Kadarzi. Hal ini menunjukkan responden yang memiliki dukungan social budaya akan mengimplementasikan Kadarzi dengan positif yaitu 43 responden $(69,4 \%)$

Hal lain yang memberikan pengaruh terhadap implementasi Kadarzi adalah kebudayaan. Faktor social budaya dapat memberi corak pengalaman individu-individu masyarakat asuhannya. Sebagai akibatnya, tanpa disadari kebudayaan telah menanamkan garis pengaruh sikap kita terhadap berbagai masalah. (Marimbi, 2010)

Berbagai budaya tentang gizi ada dimasyarakat. Banyak bahan makanan yang sesungguhnya bernilai gizi tinggi tetapi tidak digunakan atau banyak digunakan secara terbatas akibat adanya prasangka yang tidak baik terhadap bahan makanan itu. Penggunaan bahan makanan itu dianggap dapat menurunkan harkat keluarga. (Proverawati, 2010)

Berbagai kebiasaan yang bertalian dengan pantang makanan tertentu masih sering kita jumpai terutama di daerah pedesaan. Larangan terhadap anak untuk makan telur, ikan atau daging hanya berdasarkan kebiasaan yang tidak ada datanya dan hanya diwarisi secara dogmatis secara turun temurun, padahal anak itu sendiri sangat memerlukan bahan makanan seperti itu guna keperluan pertumbuhan tubuhnya. Kesukaan yang berlebihan tehadap suatu jenis makanan tertentu atau disebut sebagai faddisme makanan akan mengakibatkan tubuh tidak memperoleh semua zat gizi yang diperlukan. (Proverawati, 2010)

Kemudian faktor lain adalah pengaruh orang lain yang dianggap penting dimana individu pada umumnya cenderung untuk memiliki sikap yang konformis atau searah dengan sikap seseorang yang dianggap penting kecenderungan ini antara lain dimotivasi oleh keinginan untuk menghindari konflik dengan orang yang dianggap penting tersebut (Azwar, 2008).

Menurut asusmsi peneliti Biasanya keyakinan diperoleh secara turun temurun dan tanpa adanya pembuktian terlebih dahulu. Keyakinan ini bisa mempengaruhi pengetahuan seseorang, baik keyakinan itu sifatnya positif maupun negatif. Demikian juga dengan penerapan gizi pada Balita.

d. Hubungan Pendidikan dengan Implementasi Program Keluarga Sadar Gizi (Kadarzi)

Berdasarkan hasil penelitian diketahui bahwa mayoritas responden memiliki pendidikan menengah yaitu 63 responden $(63 \%)$. Berdasarkan hasil analisa bivariate diketahui bahwa terdapat hubungan yan signifikan antara tingkat pendidikan dengan implementasi Kadarzi $P$ value 0,018 $(\mathrm{p}<0,005)$. 
Pendidikan berarti bimbingan yang diberikan seseorang kepada orang lain agar dapat memahami sesuatu hal. Tidak dapat dipungkiri bahwa semakin tinggi pendidikan seseorang, semakin mudah pula mereka menerima informasi, dan pada akhirnya pengetahuan yang dimilikinya akan semakin banyak. Sebaliknya, jika seseorang memiliki tingkat pendidikan rendah, maka akan menghambat perkembangan sikap orang tersebut terhadap penerimaan informasi dan nilai-nilai yang baru diperkenalkan (Mubarak, 2012).

Menurut UU Sisdiknas Pendidikan menengah merupakan lanjutan pendidikan dasar. Pendidikan menengah terdiri atas: pendidikan menengah umum, dan pendidikan menengah kejuruan. Pendidikan menengah berbentuk: Sekolah Menengah Atas (SMA), Madrasah Aliyah (MA), Sekolah Menengah Kejuruan (SMK), dan Madrasah Aliyah Kejuruan (MAK), atau bentuk lain yang sederajat.

Pendidikan merupakan factor penting dalam proses tumbuh kembang anak. Syafli (2011) menyatakan keadaan tingkat pendidikan orang tua yang rendah, terutama ibu berpengaruh terhadap perilaku ibu dalam mengelola rumah tangga, terutama pola konsumsi pangan sehari-hari.

Tingkat pendidikan sangat mempengaruhi kemampuan penerimaan informasi mengenai gizi dan kesehatan anak. Semakin tinggi pendidikan maka seseorang akan lebih mudah menerima informasi gizi. Pada ibu dengan tingkat pendidikan yang rendah, pengetahuan tentang kesehatan dan perkembangan anak minimal hanya sekedar pengetahuan dan kebiasaan mengasuh yang diperolehnya dari orang tua dan tetangga yang mungkin memiliki taraf pendidikan dan pengalaman yang juga kurang, sehingga menjadi faktor yang menghambat ibu dalam melakukan pengasuhan anak yang maksimal

Hasil penelitian ini juga didukung oleh penelitian Nazaruddin: 2013 yang menyatakan bahwa terdapat hubungan yang signifikan antara pendidikan dengan praktik Kadarzi $(p$ value: 0,037).
Faktor dari lembaga pendidikan dan lembaga agama merupakan konsep moral dan ajaran yang sangat menentukan sistem kepercayaan. Tidaklah mengherankan apabila pada gilirannya konsep tersebut mempengaruhi sikap dan prilaku. Tingkat pendidikan ibu merupakan modal utama dalam menunjang ekonomi keluarga, juga berperan dalam penyusunan keluarga dan pengasuhan dan perawatan anak. Bagi keluarga dengan tingkat pendidikan tinggi akan dengan mudah menerima inforasi kesehatan khususnya bidang gizi sehingga dapat menambah pengetahuan dan mampu menerapkan dalam kehidupan sehai-hari. Beberapa penelitian menunjukkan jika tingkat pendidikan dari ibu meningkat maka pengetahuan nutrisi dan praktik nutrisi bertambah baik

\section{Simpulan}

Simpulan penelitian ini adalah factorfaktor yang secara statistik memiliki kemaknaan signifikan mempengaruhi implementasi Program Keluarga Sadar Gizi (Kadarzi) pada ibu yang memiliki Balita adalah Pengetahuan $(P$ value 0,025$)$, Sikap $(P$ value 0,003), Sosial Budaya

$(P$ value 0,029), dan Pendidikan (P value 0,018$)$..

Saran dalam penelitian ini adalah dalam memberikan asuhan kebidanan bidan khususnya penyuluhan kesehatan tentang gizi pada Balita terutama tentang implementasi Program Keluarga Sadar Gizi (Kadarzi) bidan harus memperhatikan factor-faktor yang akan mempengaruhi ibu dalam mengimplementasikan program Keluarga Sadar Gizi (Kadarzi) yaitu pengetahuan ibu, sikap ibu, dukungan dari social budaya dan pendidikan ibu sehingga ibu dapat meningkatkan gizi keluarga khususnya Balita dengan implementasinya program Kadarzi.

\section{Referensi}

Arbella.VM. (2013). Hubungan Pengetahuan dan Sikap Ibu tentang Keluarga Sadar Gizi (Kadarzi) dengan Prilaku Sadar Gizi Keluarga Balita di Desa Karangsono Kecamatan Kwadungan 
Kabupaten Ngawi. Jurnal Kebidanan Vo.2 No.5. Oktober 2013.

Azwar, S. (2008). Sikap Manusia Teori dan Pengukurannya; Edisi ke-2. Yogyakarta; Pustaka Pelajar Offset.

Denny, S. \& Helmy, R. (2013). http://ejurnal.poltekkes-

tkj.ac.id/index.

php/JKEP/article/view/261. Diperoleh tanggal 152 November 2018.

Departemen Kesehatan. (2007). Keputusan Mentri Kesehatan Republik Indonesia Nomor: $\quad$ 747/Menkes/SK/VI/2007 tentang Pedoman Operasional Keluarga Sadar Gizi di Desa Siaga. Direktorat Jendral Bina Kesehatan Masyarakat. Direktorat Bina Gizi Masyarakat.

Strategi KIE Keluarga Gizi (KADARZI). Dapertemen Kesehatan Direktorat Jendral Bina Kesehatan Masyarakat. Direktorat Bina Gizi Masyarakat.

Dinas Kesehatan Provinsi Riau. (2016). Profil Kesehatan.

Global Hunger Indenx (2019). https://www.globalhungerindex.org diperoleh tanggal 30 Agustus 2019.

Kementrian Kesehatan RI. (2014). Pedoman Gizi Seimbang. Direktorat Jenderal Bina Gizi dan Kesehatann Ibu dan Anak. . (2017). Buku Saku

Pemantuan Status Gizi Tahun 2017.

(2018). Profil

Kesehatan Indonesia Tahun 2017.

Marimbi, H. (2010). Tumbuh Kembang, Status Gizi \& Imunisasi Dasar pada Balita. Yogyakarta; Nuha Medika.

Maulana, H. (2012). Promosi Kesehatan. Jakarta; EGC.

Menteri Kesehatan RI. (2014). Peraturan Menteri Kesehatan Republik
Indonesia Nomor 23 Tahun 2014 tentang Upaya Perbaikan Gizi.

Mubarak, W.I. (2012). Promosi Kesehatan untuk Kebidanan. Jakarta; Salemba Medika.

Nazaruddin. (2013). Hubungan Karakteristik Keluarga dan Pemberdayaan Masyarakat dengan Praktik Kadarzi di kecamatan trienggadeng Kebupaten pidi jaya. Medan; FKM USU.

Notoatmodjo, S. (2010). Promosi Kesehatan Teori \& Aplikasi. Jakarta: Rineka Cipta.

. (2012). Promosi Kesehatan dan Perilaku Kesehatan. Jakarta: Rineka Cipta.

Proverawati, A. \& Asfuah, S. (2009). Buku Ajar Gizi untuk Kebidanan. Yogyakarta; Nuha Medika.

Putri, R.F. dkk. (2015). http://jurnal.fk.unand.ac.id/index.php/ jka/article/download $\quad / 231 / 225$ diperoleh pada tanggal 5 Februari 2019.

Septian D, Helmy R. (2013) Pengetahuan dan sikap keluarga dengan prilaku keluarga sadar gizi (Kadarzi). Jurnal Ilmiah Keperawatan Sai Betik. Vo.9 No.1. http://ejurnal.poltekkes-tjk.ac.id diperoleh tgl 18 Desember 2019.

Setyaningsih, S.R. \& Agustini, N. (2014). http://jki.ui.ac.id/index.php/jki/ article/viewFile/451/565 diperoleh pada tanggal 22 November 2018.

Suhana, N. (2013). Hubungan Pengetahuan Ibu tentang Keluarga Sadar Gizi Balita, 23-26, 36-37.

Supariasa, D.N. dkk. (2013). Penilaian Status Gizi. Jakarta; EGC.

Susanti, R. dkk. (2014) http://media.neliti.com/media/publicat ions/106951-ID- pengetahuan-sikap- 
dan-perilaku-ibu-dalam.pdf diperoleh tanggal 20 November 2018.

Syafli.H. (2011) Hubungan Prilaku Keluarga Sadar Gizi (Kadarzi) dengan Status gizi Balita di Kota Jambi. Departemen Gizi Masyarakat Fakultas ekolog Manusia, IPB. Bogor. Undang-Undang Republik Indonesia Nomor 20 Tahun 2003 tentang Sistem Pendidikan Nasional. http://kelembagaan.ristekdikti.go.id/w p-content/uploads

/2016/08/UU_no_20_th_2003.pdf diperoleh tanggal 25 Oktober 2018 